\title{
A case of rare pediatric unclassified NK/T cell lymphoma
}

\author{
Andrey V. Kozlov ${ }^{1}$, Olga I. Bogdanova ${ }^{1}$, Asmik G. Gevorgian ${ }^{1}$, Egor V. Volchkov ${ }^{2}$, Anna V. Botina ${ }^{1}$, Vadim V. Baykov ${ }^{1}$, \\ Elena V. Morozova ${ }^{1}$, Natalya B. Mikhailova ${ }^{1}$, Ludmila S. Zubarovskaya ${ }^{1}$ \\ ${ }^{1}$ RM Gorbacheva Research Institute of Pediatric Oncology, Hematology and Transplantology, Pavlov University, St. Petersburg, \\ Russia \\ ${ }^{2}$ Dmitry Rogachev National Research Center, Moscow, Russia
}

Dr. Andrey V. Kozlov, RM Gorbacheva Research Institute

E-mail: kozlovandrew1983@yandex.ru of Pediatric Oncology, Hematology and Transplantology, Pavlov University, L. Tolstoy St, 197022, St. Petersburg, Russia

Citation: Kozlov AV, Bogdanova OI, Gevorgian AG et al. A case of rare pediatric unclassified NK/T cell lymphoma. Cell Ther Transplant 2021; 10(3-4): 54-60.

\section{Summary}

The article presents a case report of rare unclassified peripheral T-cell lymphoma (PTCL) in a child. The disease was characterized by refractory course and addition of immune checkpoint inhibitors (ICI) to chemotherapy resulted in remission induction. The rationale for immunotherapy was presence of programmed cell death ligand 1 (PDL1) on the cells of tumor microenvironment. First remission was consolidated with autologous hematopoietic stem cell transplantation (HSCT), and second remission was followed by allogeneic HSCT.
Post-transplant period was complicated by severe acute graft-versus-host disease (GVHD) successfully managed with ruxolitinib. To perform local control, intrathecal cytostatic therapy was used prior to HSCT and post-transplant. Three years after last transplantation, the patient is disease-free and GVHD-free, with overall good quality of life and only mild impairment of cognitive functions.

\section{Keywords}

Peripheral T-cell lymphoma, children, chemoimmunotherapy, hematopoietic stem cell transplantation.

\section{Introduction}

PTCL is a rare neoplasm in children and there are no standards and decisively effective approaches in the therapy. A number of subtypes with specific morphologic and clinical features comprise the diversity of this entity. Survival in children with PTCL is lower compared to other types of pediatric non-Hodgkin lymphoma (NHL) and is approximately $60 \%$. Patients with non-anaplastic PTCL-not otherwise specified have higher chance of cure compared to other subtypes. According to World Health Organization, more than 20 subtypes of PTCL are recognized $[1,2]$. PTCL is a diagnostic challenge with common mistakes occurring at initial diagnosis. Among 69 patients in Berlin-Frankfurt-Munster (BFM) database, the diagnosis was confirmed after reference only in 38 children (55\%) [3]. Recent classification is based on adult data, and there are some concerns if it can be completely extrapolated in pediatric cohort. Distribution of
PTCL subtypes differs with age, and there are often pre-existing conditions in $25 \%$ of pediatric patients, e.g., primary immunodeficiency, prior chemotherapy, etc. [4].

Natural killer (NK) cell lymphoblastic lymphoma/leukemia is uncommon pathology with only case reports published [5]. Its rarity prevents investigation of tumor biology and optimal treatment approaches. To establish this diagnosis, a combination of CD56 and immature T cell-associated markers should be present on the lymphoblasts. Misdiagnosis is a common situation with common discrepancies among pathologists on exact final diagnosis. Prognosis is dismal in these patients. Prior to WHO 2008 classification, the NK cell lymphoblastic lymphoma/leukemia was attributed to PTCL [6]. Nowadays, the disease is related to ambiguous leukemia [7].

The present case report illustrates 7-year-old child with unclassified NK/T cell lymphoma with blast morphology. 
The closest clinical entity in WHO classification is NK/T cell lymphoma, and it should be attributed to PTCL [8]. At the same time, blast morphology and clinical presentation share features of lymphoblastic lymphoma.

\section{Case description}

Six-year-old otherwise healthy boy presented with febrile temperature, generalized macular/papular rash, hepatosplenomegaly and facial swelling. The onset of disease was sudden (15.01.2017). Initially, the patient was diagnosed with hemophagocytic lymphohistiocytosis, due to fever, progressive hepatosplenomegaly and increased ferritin level (535 $\mathrm{ng} / \mathrm{ml}$ ). The disease rapidly progressed, and pneumonia with pleuritis developed in several days, thus requiring admission to intensive care unit. Specific therapy with steroids, etoposide, intravenous immunoglobulins and cyclosporine A was started with transient response and further progression with enlargement of left testis, which was biopsied on March 29, 2017. Initial histological analysis in local lab demonstrated extranodal NK/T cell lymphoma, nasal type. Later on, the histology was revised in RM Gorbacheva Research Institute, Pavlov University (St. Petersburg), and the diagnosis was switched to NK/T lymphoma with blast morphology. The revised histology revealed overgrowth of lymphoid smalland middle-sized cells with narrow cytoplasmic area. The cells contained irregular and roundish nuclei with finely dispersed chromatin. Some nuclei contain solitary tiny nucleoli (Fig. 1).

Immunohistochemical study showed intensive expression of CD2, CD3, CD5, CD7, CD56, granzyme B, and co-expression of CD4 and CD8. Most cells were slightly CD33-positive.

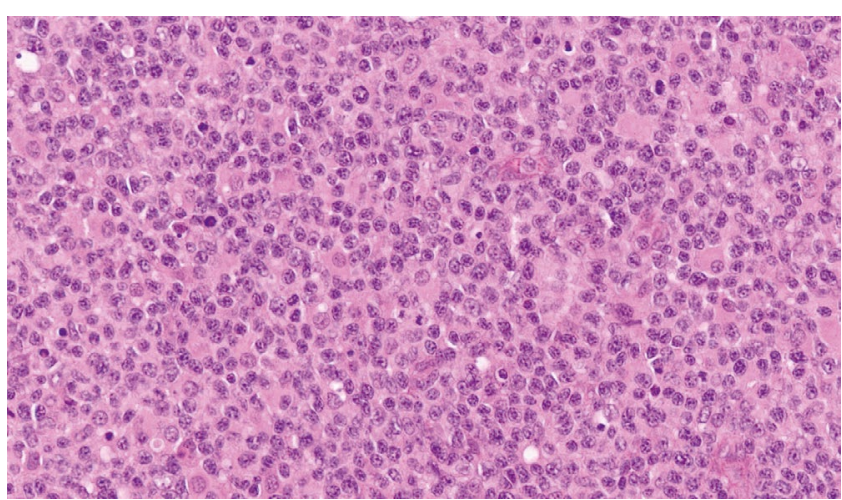

Figure 1. Histology of testicular bioptate (H\&E staining)

There was no detectable expression of CD30, CD57, CD99, TdT, CD1a, CD10. In situ hybridization failed to demonstrate presence of Epstein-Barr virus. Index of proliferative activity (Ki-67) was elevated (70-80\%). PDL1 was not expressed on tumor cells but was clearly detectable on tumor microenvironment cells (macrophages) (Fig. 2 A-I). On the basis of these pathological findings, the pathologist concluded that the tumors with such immunophenotype were not previously described under known classifications. Extranodal NK/T cell lymphoma, nasal type, and blastic plasmacytoid dendritic cell neoplasm were excluded. This is an unclassified lymphoma with the features of peripheral $\mathrm{T}$ cell and lymphoblastic lymphoma (Fig. 2). It is typical for NK-cells to express CD2, CD16 and CD56. Presence of these molecules on tumor cells together with the absence of clonal receptor gene rearrangements are characteristic for NK-cell lymphomas [8].

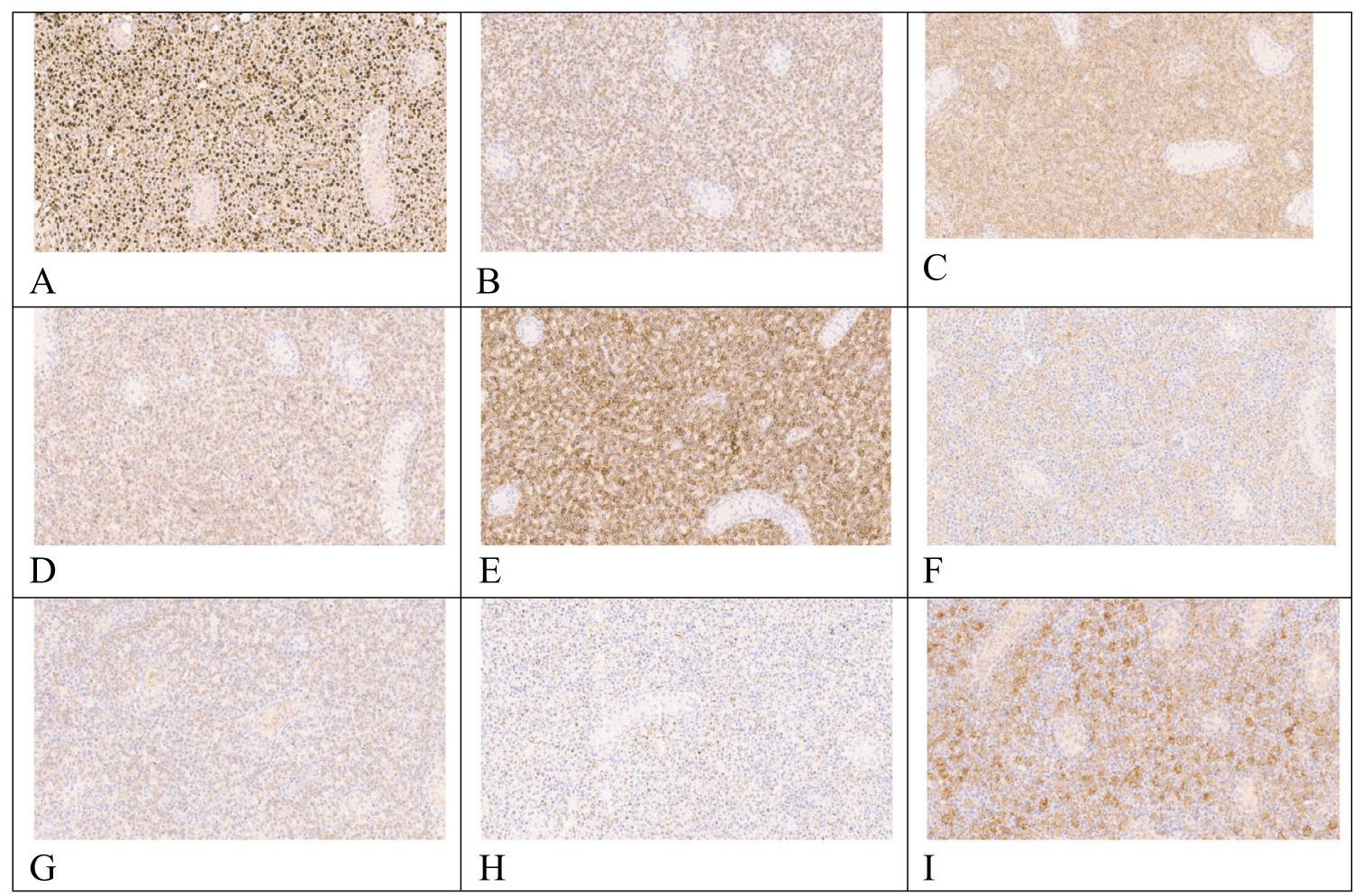

Figure 2. Immunohistochemistry pattern of the unclassified NK/T cell lymphoma (testicular biopsy). Staining with antibodies for the following antigens: Ki-67 (A), CD3 (B); CD4 (C); CD5 (D); CD8 (E); CD33 (F); CD56 (G); Granzyme B(H), PDL1 (I) 
Molecular biological analysis revealed mutation in enhancer of Zeste homolog 2 (EZH2) gene (p.Arg288Gln) in 5\% of tumor cells.

Polychemotherapy according to SMILE protocol was started on 13 April 2017. Treatment schedule consisted of dexamethasone $20 \mathrm{mg} / \mathrm{m}^{2}$ №4, methotrexate $2000 \mathrm{mg} / \mathrm{m}^{2}$ №1, ifosfamide $1500 \mathrm{mg}$ №3, L-asparaginase $6000 \mathrm{mg} / \mathrm{m}^{2}$ №7, and etoposide $100 \mathrm{mg} / \mathrm{m}^{2}$ №3. Due to presence of effusions and risk of unacceptable toxicity, methotrexate was skipped in the first cycle. Other drugs, doses and timing were applied according to standard protocol [9]. In general, the patient received 4 courses of SMILE (13.04.17 -2.08.17). Aggressive progression after the fourth cycle of SMILE with involvement of liver, left testis and CNS was registered (15 August 2017). Active disease was confirmed by presence of tumor cells in the cytology specimens of left testis and cerebrospinal fluid. Bone marrow was not affected. Multiple rash elements that were present upon progression did not exhibit tumor biology, and were associated with paraneoplastic process, as revealed by biopsy.

The second-line induction therapy consisted of FLAG (fludarabine $30 \mathrm{mg} / \mathrm{m}^{2}$ №5, cytarabine $4000 \mathrm{mg} / \mathrm{m}^{2}$ №5, granulocyte colony-stimulating factor) and ICI (nivolumab $40 \mathrm{mg}$ on Days $1,14,28)$. This strategy resulted into the first durable complete remission. Irradiation of testis, or orchidectomy was not performed due to refusal of parents. Further treatment consisted of nivolumab (3 mg/kg №9 biweekly, weekly gemcitabine $1000 \mathrm{mg} / \mathrm{m}^{2}$ №6, and intrathecal therapy (cytarabine $30 \mathrm{mg}$, metotrexate $12 \mathrm{mg}$, prednisolone $10 \mathrm{mg}$ ) №6. Autologous HSCT was performed on 15 February 2018 with BeEAM (bendamustine $160 \mathrm{mg} / \mathrm{m}^{2}$ on Days -7 and -6 , etoposide $200 \mathrm{mg} / \mathrm{m}^{2}$ and cytarabine $400 \mathrm{mg} / \mathrm{m}^{2}$ on Days -5 to -2 and melphalan $140 \mathrm{mg} / \mathrm{m}^{2}$ on Day -1 ) as a conditioning regimen administered for remission consolidation. Afterwards, the therapy was stopped, hoping for curation. Unfortunately, 2 months after autologous HSCT, the patient developed facial asymmetry, and cerebrospinal fluid aspirate showed presence of tumor cells upon immunophenotyping (Fig. 3).

There were no structural abnormalities on magnetic resonance imaging. Third-line therapy consisted of single dose intravenous cytarabine $1000 \mathrm{mg} / \mathrm{m}^{2}$, biweekly intrathecal therapy (cytarabine $30 \mathrm{mg}$, metotrexate $12 \mathrm{mg}$, prednisolone 10 $\mathrm{mg}$ ) №8 and biweekly nivolumab $40 \mathrm{mg}$ №9. Second complete remission was achieved during the first week of treatment. To consolidate second remission, first haploidentical HSCT (from father) was performed (25 September 2018). Non-myeloablative conditioning (busulfan $8 \mathrm{mg} / \mathrm{kg}$ and fludarabine $150 \mathrm{mg} / \mathrm{m}^{2}$ ) was used prior to transplantation. Graft-versushost disease (GVHD) prophylaxis was based on posttransplant cyclophosphamide $(100 \mathrm{mg} / \mathrm{kg})$, sirolimus and tacrolimus. Bone marrow was used as a transplant source, with total number of $8 \times 10^{6} \mathrm{CD} 34+$ cells $/ \mathrm{kg}$. There were no signs of peripheral blood recovery, and primary non-engraftment occurred (Day+30). The patient received second haploidentical HSCT on 14 October 2018 with switching to other donor and transplant source (unmanipulated peripheral blood stem cells from mother). A total of $10 \times 10^{6} \mathrm{CD} 34+$ cells $/ \mathrm{kg}$ were infused. Reduced-intensity conditioning regimen consisted of fludarabine $150 \mathrm{mg} / \mathrm{m}^{2}$ and treosulfan $36 \mathrm{mg} / \mathrm{m}^{2}$.
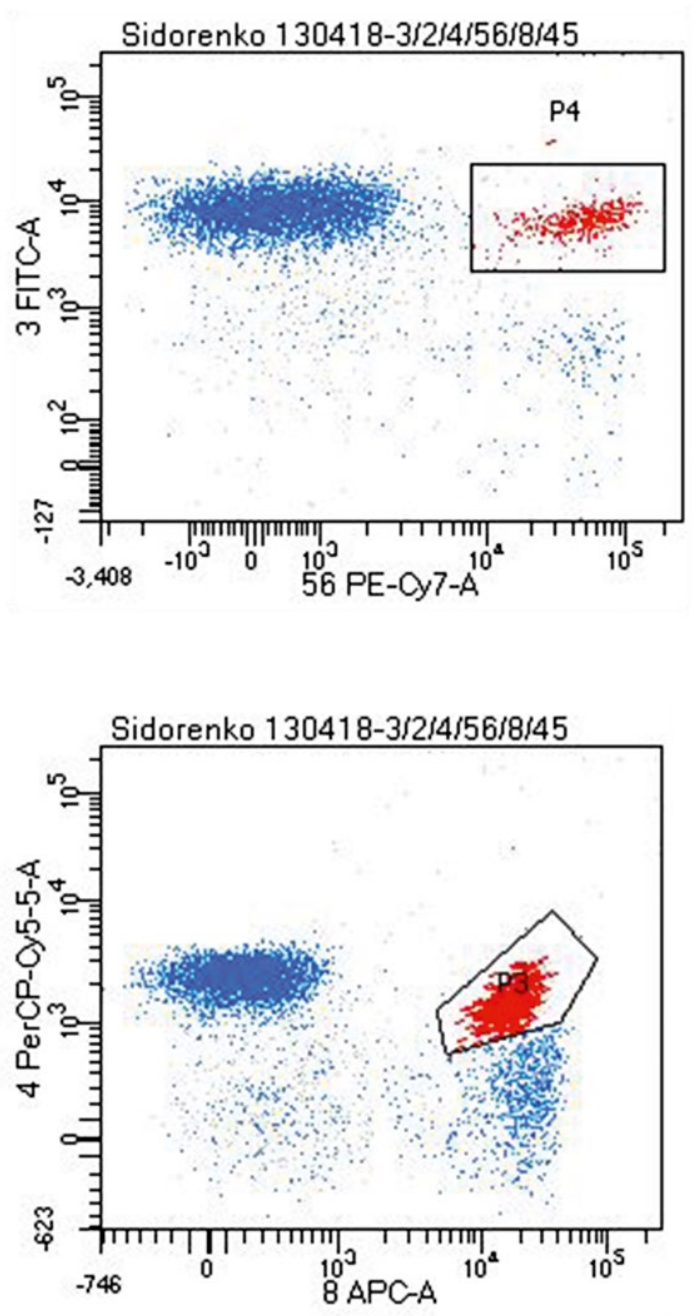

Figure 3. Immunophenotyping of cerebrospinal fluid (CD2, CD3, CD4, CD8, CD45, CD56)

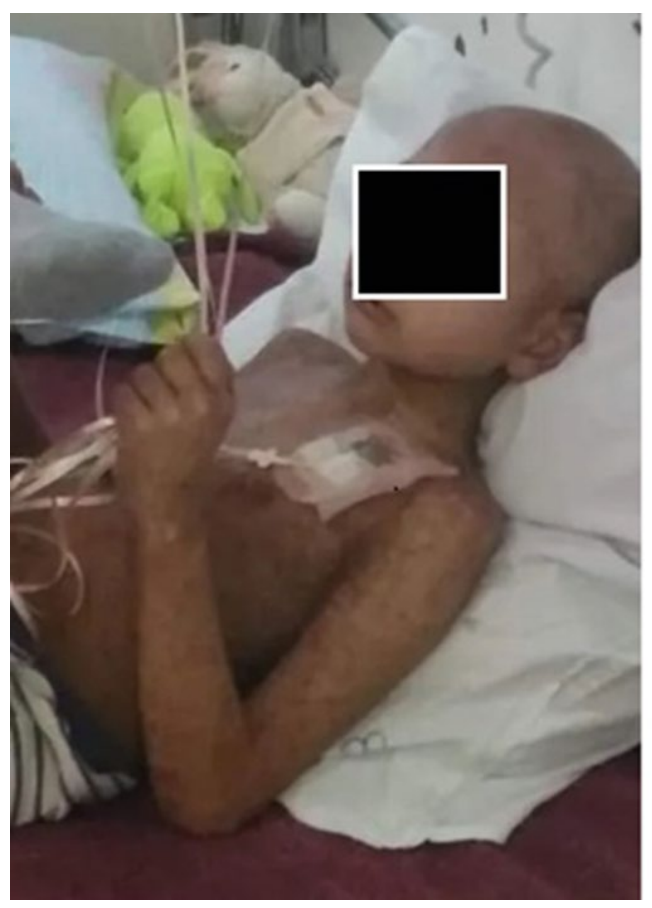

Figure 4. Acute graft-host-disease after allo-HSCT 
Posttransplant cyclophosphamide $\left(100 \mathrm{mg} / \mathrm{m}^{2}\right)$ and sirolimus were used for GVHD prophylaxis. Engraftment was diagnosed on Day +19 . Transplantation was complicated by stage IV steroid-refractory acute GVHD of skin (Day+25) that responded to ruxolitinib (Fig. 4).

The patient received monthly intrathecal therapy №6 after transplantation for the prophylaxis of CNS relapse. At the present time, he remains in complete remission without signs of GVHD and treatment-free for 3 years. There is a slight decrease in intellectual abilities that necessitated individualized learning program at school. This complication is probably associated with previous CNS affection by lymphoma and related treatment [10].

\section{Discussion}

Data on NK cell lymphoblastic leukemia/lymphoma is limited to case reports. PTCL is more common nosology, but non-anaplastic PTCL is also a rare entity in children $[2,11]$. This case report represents rare unclassified NK/T lympho$\mathrm{ma}$ in a child. According to opinion of pathologists, this type of lymphoma was not previously described in WHO classification, sharing features of both PTCL and lymphoblastic lymphoma. This fact underlines the existence of lymphoma subtypes that do not match established classification variants. Regular revision of lymphoma classifications is partially explained by the discovery of new features or detailing of established lymphoma subtypes. An EZH2 gene mutation typical to PTCL was found in the minority of tumor cells (5\%) of our patient [12]. It could be attributed to tumor heterogeneity and presence of subclone harboring the EZH2 mutation. Epstein-Barr virus (EBV) was not present in the tumor specimen. However, EBV plays an important role in the pathogenesis of many PTCL subtypes. Most extranodal NK/T lymphomas carry type A EBV. Despite certain role of EBV in NK/T cell lymphomas, exact mechanism of viral cancerogenesis is unclear in this setting [12]. Prevalence of NK/T cell lymphomas in distinct geographical regions despite worldwide EBV distribution suggests importance of ethnic genetic profile for NK/T lymphoma pathogenesis [8]. Initially, our patient was diagnosed with hemophagocytic lymphohistiocytosis (HLH) and started appropriate therapy. The diagnosis was not confirmed later since the patient did not fit all necessary HLH criteria (only 3 criteria of 5 required) [13]. Anyway, to our opinion, the initial therapy played an important role in patient rescue in the circumstances of limited time and progressive deterioration, because treatment with steroids and etoposide transiently stabilized clinical situation and gained time for correct diagnosis. Biopsy of enlarged testis became a game changer that enabled true PTCL diagnostics and corrected the subsequent therapy. Natural killer cells emerge from bone marrow and further migrate to nodal and extranodal sites. This fact can partially explain common extranodal localization of NK cell lymphomas [14]. According to Murphy classification, stage IV was diagnosed in our patient due to CNS involvement. Staging of non-Hodgkin lymphoma in adults is carried out according to Ann Arbor classification, which was primary used for Hodgkin lymphoma. In children, the modified Murphy classification is used, which was initially developed for the Burkitt and lymphoblastic lymphomas. Unlike Ann
Arbor system, the Murphy classification assigns all intrathoracic and most intra-abdominal tumors to stage III, whereas only bone marrow and central nervous system lesions are classified as stage IV [15]. According to previously published data, most children with PTCL demonstrate advanced disease at the onset expect extranodal NK/T cell lymphoma [4].

Patient failed first-line therapy of lymphoma. He could be primary refractory to the therapy, or previous treatment of HLH interfered in natural course. Another reason of chemoresistance could be application of the SMILE chemotherapy protocol designed specifically for extranodal NK/T lymphoma, since this type of PTCL was initially diagnosed. There is no established treatment for non-anaplastic PTCL in children. Various treatment protocols, such as anaplastic large-cell lymphoma therapy or acute leukemia protocols are used with comparable efficiency $[3,16]$. The treatment results vary between PTCL subgroups, indicating that a subtype-specific approach should be pursued. Except for subcutaneous panniculitis-like T-cell lymphoma, survival rates are poor and the optimal treatment strategy has not been defined yet. International registry with treatment recommendations is needed to improve outcomes for this rare and heterogeneous group of diseases. Results in adult PTCL after CHOP or other treatment approaches are disappointing [17, 18]. Difficulties in PTCL management are associated with unique tumor biology and rarity of the disease that prevents multicentre randomized clinical trials, especially in pediatric population. Prognosis in R-R non-anaplastic PTCL is dismal, with median OS of only 5.8 months. Our patient demonstrated progression of the disease after first-line therapy, and the panel of doctors decided to start FLAG protocol combined with nivolumab. This was a non-standard recommendation, since the second-line therapies in PTCL usually include platinum and/or gemcitabine [19]. Our choice was based on leukemia-like clinical features (involvement of CNS and testis), blast morphology of tumor cells and presence of PDL1 expression on tumor microenvironment. There are no data on combination of nivolumab with FLAG, but combination of nivolumab with cytarabine or fludarabine is feasible according to recently published data [20,21]. Extranodal NK-cell lymphomas are more common in patients with definite HLA haplotypes while rarely occur in patients with other haplotypes suggesting that immune surveillance is important for this tumor. Thus, one may hypothesize on immunotherapy as a potentially effective approach in this clinical setting [22]. Informed consent was obtained from relatives of the patient prior to starting the therapy. This treatment plan resulted in first continuous complete remission. Further treatment was based on systemic immunochemotherapy (nivolumab and gemcitabine) combined with local tumor control (intrathecal therapy). The rationale for this approach was presence of PDL1 on tumor microenvironment, and published data on possible effectiveness of ICI in pediatric PTCL [24]. First remission was consolidated with autologous HSCT according to established recommendations for refractory NHL in children [25]. Allogeneic HSCT was reserved for further treatment if required. Previous therapy with nivolumab and, therefore, increased risk of severe GVHD was an important counter-argument for the ongoing allogeneic HSCT [26]. The role of allogeneic transplant in the management of pediatric R-R PTCL patients remains unclear. According 
to results obtained in adults, allo-HSCT may be beneficial in PTCL, due to graft-versus-tumor effect [27]. Allo-HSCT may be similarly effective as consolidation after first or second remission, being not a good option at progression [28]. Data in children with PTCL and HSCT are limited to sporadic reports and are not decisive [4]. Due to early relapse of lymphoma after autologous HSCT in our patient, the re-treatment with nivolumab and intrathecal therapy was initiated which resulted into second complete remission. There were no doubts that this was the optimal point for consolidation of second remission with allo-HSCT. Moreover, due to aggressive and unpredictable disease course there was no benefit for searching a matched unrelated donor. For the first haploidentical HSCT, a non-myeloablative conditioning regimen was chosen based on previous autologous HSCT. Unfortunately, this approach led to primary non-engraftment, probably, due to residual recipient cells that promoted the graft rejection. Risks of non-engraftment with standard transplant approaches with haploidentical stem cell source are well known and can be ameliorated with higher number of infused stem cells, more intense conditioning regimens and additional techniques of transplant processing $[29,30]$. To enable engraftment, the second haploidentical HSCT was performed with more intense conditioning regimen and peripheral blood stem cells as transplant source. This procedure resulted into engraftment, but early posttransplant period was complicated with severe steroid-refractory cutaneous acute GVHD that responded to ruxolitinib. Further on, the patient underwent prophylactic intrathecal therapy due to high risk of CNS relapse and low effectiveness of graft-versus-tumor effect in the controlling barrier areas [31].

The limitation of this case report is absence of survey for underlying primary immunodeficiency syndrome, because many children with PTCL have some pre-existing disorders affecting immune system.

The present report demonstrates a case of rare unclassified NK/T cell lymphoma that was successfully treated with chemoimmunotherapy and repeated transplantations. No doubt, this tumor was sensitive to immunotherapy. Hence, the immune checkpoint inhibitors followed by allogeneic transplantation may be effective in therapy of pediatric PTCL.

\section{Conflict of interest}

None declared.

\section{References}

1. Swerdlow SH, Campo E, Pileri SA, Harris NL, Stein H, Siebert R, et al. The 2016 revision of the World Health Organization classification of lymphoid neoplasms. Blood. 2016;127(20):2375-2390. doi: 10.1182/blood-2016-01-643569

2. Maciejka-Kemblowska L, Chaber R, Wrobel G, Maldyk J, Kozlowska M, Kulej D, et al. Clinical features and treatment outcomes of peripheral T-cell lymphoma in children. A current data report from Polish Pediatric Leukemia/Lymphoma Study Group (PPLLSG). Adv Med Sci. 2016; 61(2):311-316. doi: $10.1016 /$ j.advms.2016.03.002
3. Kontny U, Oschlies I, Woessmann W, Burkhardt B, Lisfeld J, Salzburg J et al. Non-anaplastic peripheral T-cell lymphoma in children and adolescents - a retrospective analysis of the NHL-BFM study group. Br J Haematol. 2015; 168(6):835-844. doi: 10.1111/bjh.13216

4. Mellgren, K, Attarbaschi A, Abla, O, Alexander S, Bomken S, Bubanska E, et al. Non-anaplastic peripheral T cell lymphoma in children and adolescents - an international review of 143 cases. Ann Hematol. 2016; 95:1295-1305. doi: 10.1007/s00277-016-2722-y

5. Jain S, Kumar R, Purohit A, Pati HP. Precursor NK cell lymphoblastic leukemia/lymphoma - report of a case with literature review. Ind J Hematol Blood Transfus. 2014; 30 (Suppl 1):283-285. doi: 10.1007/s12288-014-0360-X

6. Frenkel' MA, Baranova O Yu, Antipova AS, Kupryshina NA, Tupitsyn NN. NK-cell lymphoblastic leukemia/ lymphoma (literature review and authors' experience). Clinical Oncohematology. 2016;9(2):208-217 (In Russian). doi: $10.21320 / 2500-2139-2016-9-2-208-217$

7. Arber DA, Orazi A, Hasserjian R, Thiele J, Borowitz MJ, Le Beau MM, et al. The 2016 revision to the World Health Organization classification of myeloid neoplasms and acute leukemia. Blood. 2016;127(20):2391-2405. doi: 10.1182/ blood-2016-03-643544

8. Tse E, Kwong YL. The diagnosis and management of NK/T-cell lymphomas. J Hematol Oncol 10, 85 (2017). doi: $10.1186 / \mathrm{s} 13045-017-0452-9$

9. Yamaguchi M, Kwong YL, Kim WS, Maeda Y, Hashimoto C, Suh C, et al. Phase II study of SMILE chemotherapy for newly diagnosed stage IV, relapsed, or refractory extranodal natural killer (NK)/T-cell lymphoma, nasal type: the NK-Cell Tumor Study Group study. J ClinOncol. 2011; 29(33):4410-4416. doi: 10.1200/JCO.2011.35.6287

10. Turhan AB, Tülin Fidan S, Yarar C, NazlıSakallı E, Özdemir ZC, Bör Ö. Neurocognitive consequences of childhood leukemia and its treatment. Ind J Hematol Blood Transfus. 2018;34(1):62-69. doi: 10.1007/s12288-017-0846-4

11. Al Mahmoud R, Weitzman S, Schechter T, Ngan B, Abdelhaleem M, Alexander S. Peripheral T-cell lymphoma in children and adolescents: a single-institution experience. J Pediatr Hematol Oncol. 2012; 34(8):611-616. doi: 10.1097/ $\underline{\text { MPH.0b013e3182707592 }}$

12. Zhang H, Lv H, Jia X, Hu G, Kong L, Zhang T, et al. Clinical significance of enhancer of zeste homolog 2 and histone deacetylases 1 and 2 expression in peripheral T-cell lymphoma. Oncol Lett. 2019;18(2):1415-1423. doi: $10.3892 /$ $\underline{\text { ol.2019.10410 }}$

13. Grzybowski B, Vishwanath VA. Hemophagocytic lymphohistiocytosis: A diagnostic conundrum. J Pediatr Neurosci. 2017;12(1):55-60. doi: 10.4103/jpn.JPN_140_16

14. Bekiaris V, Lane PJL. The localization and migration of natural killer cells in health and disease. Natural Killer Cells. 2010; 137-153. doi: 10.1016/B978-0-12-370454-2.00010-7 
15. Rosolen A, Perkins SL, Pinkerton CR, Guillerman GR, Sandlund JT, Reiter A, et al. Revised international pediatric non-Hodgkin lymphoma staging system. J Clin Oncol. 2015; 33 (18):2112-2118. doi: 10.1200/JCO.2014.59.7203

16. Windsor R, Stiller C, Webb D. Peripheral T-cell lymphoma in childhood: population-based experience in the United Kingdom over 20 years. Pediatr Blood Cancer. 2008; 50(4): 784-787. doi: 10.1002/pbc.21293. PMID: 18022899

17. Ma H, Bin Cheng, O'Connor OA. Survival outcomes of patients with peripheral T-cell lymphomas (PTCL) treated with chemotherapy and/or novel agents: The Columbia University experience. J Clin Oncol. 2019; 37:15 (Suppl), e19049-e19049. doi: 10.1200/JCO.2019.37.15 suppl.e19049

18. Lepik EE, Kozlov AV, Borzenkova ES, Zalyalov YR, Lepik KV, Kondakova EV, et al. Treatment options for T-cell lymphomas: a single-center study. Cell Ther Transplant. 2020; 9(1): 28-37. doi: 10.18620/ctt-1866-8836-2020-9-1-28-37

19. Foster C, Kuruvilla J. Treatment approaches in relapsed or refractory peripheral T-cell lymphomas. F1000Res. 2020;9:F1000 Faculty Rev-1091. Published 2020 Sep 4. doi: 10.12688/f1000research.22257.1

20. Ravandi F, Assi R, Daver N, Benton CB, Kadia T, Thompson PA et al. Idarubicin, cytarabine, and nivolumab in patients with newly diagnosed acute myeloid leukaemia or high-risk myelodysplastic syndrome: a single-arm, phase 2 study. Lancet Haematol. 2019; 6(9):e480-e488. doi: 10.1016/ $\underline{\text { S2352-3026(19)30114-0 }}$

21. Creelan, BC, Wang, C, Teer, JK, Toloza EM, Yao J, Kim $\mathrm{S}$, et al. Tumor-infiltrating lymphocyte treatment for antiPD-1-resistant metastatic lung cancer: a phase 1 trial. Nat Med. 2021; 27: 1410-1418. doi: 10.1038/s41591-021-01462-y

22. Kanno H, Kojya S, Li T, Ohsawa M, Nakatsuka S, Miyaguchi $\mathrm{M}$, et al. Low frequency of HLA-A ${ }^{\star} 0201$ allele in patients with Epstein-Barr virus-positive nasal lymphomas with polymorphic reticulosis morphology. Int J Cancer. 2000; 87(2):195-199. doi: 10.1002/1097-0215(20000715)87:2<195::AID-IJC6>3.0. $\underline{\mathrm{CO} ; 2-0}$

23. Sedick Q, Alotaibi S, Alshieban S, Naheet KB, Elyamany G. Natural killer cell lymphoblastic leukaemia/lymphoma: case report and review of the recent literature. Case Rep Oncol. 2017; 10(2): 588-595. doi: 10.1159/000477843

24. Kozlov AV, Kazantsev IV, Yukhta TV, Tolkunova PS, Gevorgyan AG, Lepik KV, et al. The use of checkpoint inhibitors in children with non-Hodgkin lymphomas. Pediatric Hematology/Oncology and Immunopathology. 2020; 19(2):112120. (In Russian). doi: 10.24287/1726-1708-2020-19-2-112$\underline{120}$

25. Afanasyev BV, Afanasyeva KS, Barabanshchikova MV, Bondarenko SN, Bykova TA, Vlasova JYu, Gevorgian AG, et al. Indications for hematopoietic stem cell transplantation. December 2019. Cell Ther Transplant. 2019; 8(4):101-145 (In Russian). doi: 10.18620/ctt-1866-8836-2019-8-4-101-145

26. Ijaz A, Khan AY, Malik SU, Faridi W, Fraz MA, Usman $\mathrm{M}$, et al. Significant risk of graft-versus-host disease with exposure to checkpoint inhibitors before and after allogeneic transplantation. Biol Blood Marrow Transplant. 2019; 25(1):

\section{4-99. doi: 10.1016/j.bbmt.2018.08.028}

27. Castagna L, Pagliardini T, Bramanti S, Schiano JM, de Oca CM, Bouabdallah R, et al. Allogeneic stem cell transplantation in poor prognosis peripheral T-cell lymphoma: the impact of different donor type on outcome. Bone Marrow Transplant. 2021; 56: 883-889. doi: 10.1038/s41409-020$\underline{01133-5}$

28. Mamez AC, Dupont A, Blaise D, Chevallier P, Forcade E, Ceballos $\mathrm{P}$, et al. Allogeneic stem cell transplantation for peripheral T cell lymphomas: a retrospective study in 285 patients from the Société Francophone de Greffe de Moelle et de Thérapie Cellulaire (SFGM-TC). J Hematol Oncol. 2020; 13(1):56. Published 2020 May 19. doi: 10.1186/s13045-02000892-4

29. Motorin DV, Badaev RS, Babenetskaya DV, Ilyina NA, Silina TO, Baratashvili GG, et al. Haploidentical Hematopoietic Stem Cell Transplantation (Haplo-SCT) with Post-Transplant Cyclophosphamide for haematological malignancies: a single centre experience. Cell Ther Transplant. 2016; 5(3):51-53. doi: $10.18620 / \mathrm{ctt}-1866-8836-2016-5-3-51-53$

30. Maschan MA. Depletion of alpha/beta-T-cells is a robust platform for haploidentical hematopoietic stem cell transplantation results improvement. Russian Journal of Pediatric Hematology and Oncology. 2015; 2(3):34-38. (In Russian). doi: $10.17650 / 2311-1267-2015-2-3-34-38$

31. OstronoffF, Ostronoff M, Fernandes HS, Buessio R, Soriano $\mathrm{S}$, Souto-Maior AS, et al. Evidence for a graft-versus-leukemia effect in the central nervous system. Leukemia \& Lymphoma. 2008; 49(2): 365-369. doi: 10.1080/10428190701784417 


\title{
| Редкая неклассифицируемая НК/Т-клеточная лимфома у ребенка
}

\author{
Андрей В. Козлов ${ }^{1}$, Ольга И. Богданова ${ }^{1}$, Асмик Г. Геворгян ${ }^{1}$, Егор В. Волчков ${ }^{2}$, Анна В. Ботина ${ }^{1}$, Вадим В. Байков ${ }^{1}$, \\ Елена В. Морозова ${ }^{1}$, Наталия Б. Михайлова ${ }^{1}$, Людмила С. Зубаровская ${ }^{1}$ \\ ${ }^{1}$ НИИ детской онкологии, гематологии и трансплантологии им. Р. М. Горбачевой, Первый Санкт-Петербургский \\ государственный медицинский университет им. акад. И. П. Павлова, Санкт-Петербург, Россия \\ ${ }^{2}$ НМИЦ ДГОИ им. Дмитрия Рогачева, Москва, Россия
}

\section{Резюме}

Статья представляет собой демонстрацию клинического случая редкой неклассифицируемой периферической Т-клеточной лимфомы у ребенка. Заболевание характеризовалось рефрактерным течением. Ремиссия была получена после добавления ингибиторов иммунных контрольных точек (ИКТ) к химиотерапии. Основанием для начала иммунотерапии было присутствие PDL1 (лиганд рецептора программируемой клеточной смерти 1) на клетках микроокружения опухоли. Для консолидации первой ремиссии была проведена аутологичная ТГСК и для консолидации второй ремиссии - аллогенная. Течение посттрансплантационного периода осложнилось тяжелой реакцией «трансплантат против хозяина» (РТПХ) с поражением кожи, которая была вылечена с помощью руксолитиниба.
Для лечения и профилактики лимфомы ЦНС применялись интратекальные введения цитостатиков как до, так и после ТГСК. Пациент находится в полной ремиссии и без признаков РТПХ в течение 3-х лет после окончания лечения. В целом, качество жизни у ребенка хорошее, за исключением легких нарушений в когнитивной сфере.

\section{Ключевые слова}

Периферическая Т-клеточная лимфома, дети, химиоиммунотерапия, трансплантация гемопоэтических стволовых клеток. 